\title{
The pathway to a sustainable industrial society - initiative of the Research Institute for Sustainability Science (RISS) at Osaka University
}

\author{
Tohru Morioka · Osamu Saito $\cdot$ Helmut Yabar
}

Received: 23 January 2006/ Accepted: 24 April 2006/ Published online: 24 August 2006

(C) Integrated Research System for Sustainability Science and Springer Verlag 2006

\begin{abstract}
While it is widely known that sustainable development is the only sound and viable pathway for humankind's future, its attainment remains elusive despite intensive efforts and some successes. The current industrial society approach based on product and process innovation in a variety of fields is not providing the expected results in addressing this important issue. In an attempt to carry out this unavoidable task, Osaka University's Research Institute for Sustainability Science (RISS) introduces an integral and dynamic innovation system where technology plays a key role in fulfilling societal functions. This innovation system adopts a highly solution-driven approach that makes use of backcasting techniques based on long-term visions and mid-term strategic goals. Since technology management is the key to propelling effective innovation towards sustainability, we propose a technology transition management through the interaction of technology push, demand pull and institutional design, along with eight transition principles. RISS will develop this innovation system based on these three components and through the design of dynamic scenarios and their roadmaps.
\end{abstract}

T. Morioka $\cdot$ O. Saito $(\bowtie)$

Division of Sustainable Energy and Environmental

Engineering, Graduate School of Engineering,

Osaka University, 2-1 Yamadaoka, Suita,

Osaka 565-0871, Japan

e-mail: saito@see.eng.osaka-u.ac.jp

H. Yabar

Research Institute for Sustainability Science (RISS),

Center for Advanced Science and Innovation (CASI),

Osaka University, 6F, 2-1 Yamadaoka, Suita,

Osaka 565-0871, Japan
Keywords Backcasting - Innovation system · Production and consumption - Scenario design . Technology management - Technology roadmap · Sustainable industrial society $\cdot$ Technology transition

\section{Introduction}

Product and process innovations have been and still are important in addressing the problems generated by current production and consumption patterns. These innovations have led to substantial improvements in environmental efficiency (Geels 2005). In this regard, Osaka University has devised a number of new scientific technologies related to the environmental and energy fields which are the core disciplines for a transition towards sustainability. Practical application of the results of cooperation with industry, such as the reduction of environmental pressure and an increase in resource productivity, contribute to the sustainability goal from an environmental perspective.

On the other hand, we have gained a solid understanding of the difficulty of overcoming the current technological paradigm, which frequently creates barriers to environmentally friendlier technologies. We also believe it is difficult to propel an innovation system by relying simply on individual technology developments that are applications of pure and advanced curiosity-driven science based on the linear model (Bush 1945). In this sense, innovations in technology policy and technology management that ensure the continuous reduction of environmental pressure are essential means towards the goal of global sustainability. This article proposes an integral innovation system that can overcome the current technological 
paradigm and facilitate a smooth transition towards sustainability. In order to achieve this goal, we base our research on a highly solution-driven approach that makes use of backcasting techniques with long-term visions and mid-term strategic goals. As technology has become the main player in fulfilling societal needs, we introduce a technology transition management through the interaction of technology push, demand pull and institutional design, along with eight transition principles. Based on these three components and through the design of future scenarios and their roadmaps, we will achieve our sustainability-oriented goals and visions.

As a member of the Integrated Research System for Sustainability Science (IR3S), Osaka University plans to participate in this project through the establishment of the Research Institute for Sustainability Science (RISS). RISS will materialize the innovation system proposed in this article and is expected to become "a research and education base that explores viable options that contribute to global sustainability." RISS research will focus on the development and diffusion of industrial technology that aims to reduce environmental pressure while maintaining stable economic development.

\section{Scenarios and roadmap design}

Scenarios and their importance for sustainable visions

Efforts to achieve a transition to sustainability have been primarily driven by concerns about the ability of the natural carrying capacity of the earth to support the growing impact of human activities. However, sustainability means more than the environment alone. Social and economic sustainability are also at a stake (European Commission 2002). Important improvements towards a sustainability transition have been achieved through incremental and separate initiatives.
However, a much larger research effort is necessary to understand the systemic relationships among different dimensions of sustainability. We believe that the path to achieving long-term progress towards sustainable development is through the understanding of these relationships. A vision of where we want to be in the future is essential if we want to stimulate and improve research initiatives and decision-making today. We must concentrate our efforts on developing the ways and means to achieve such a vision. Hence the design of future scenarios and the roadmaps for their realization is an important step in addressing the sustainability challenge. A scenario consists of not only a future image or vision, but also of the strategies by which this is achieved and, as such, it should be seen as a dynamic story of continuous interactions and feedbacks.

\section{Scenario typologies}

Borjeson et al. (2006) argue that several typologies reflect the view that studies explore a possible, probable and/or preferable future. The classification is based on the principal questions a researcher/analyst may want to pose about the future. These questions are: what will happen?, what can happen?, and how can a specific target be reached?. Besides these main questions, there are two more aspects of the system under study that are particularly important when characterizing scenarios. These are distinguished by different angles of approach to the questions defining the categories. The first aspect is the concept of system structures - i.e., the connections and relationships among the different parts of the system as well as the boundary conditions - which govern a system's development. The second aspect of the system is the distinction between internal and external factors. Internal factors are those that are controllable by the actor in question, while external factors are outside the scope of influence of the actor (see Fig. 1).

Fig. 1 Typology of scenarios

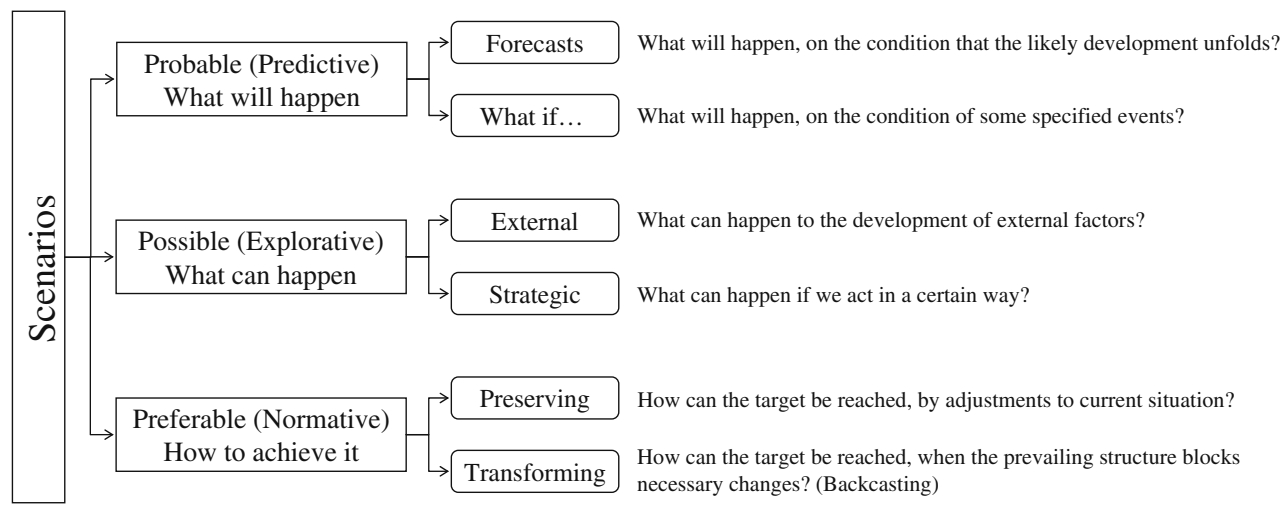


Van Notten et al. (2003) have presented an updated scenario typology in which they examine 14 characteristics of scenarios aggregated into three overarching themes: the project goal (why), process design (how) and scenario content (what). The project goal can be explorative or decision support, the process design can be intuitive or formal and the scenario content can be complex or simple. There are strong connections between these themes. The project goal influences the process design, which in turn influences the scenario content.

Among the most renowned scenarios regarding sustainability issues, two come to mind - the Intergovernmental Panel on Climate Change (IPCC) emissions scenarios and the scenarios of the Millennium Ecosystem Assessment (MA) (McDowall and Eames 2004; MA 2005; Newman 2005). Each scenario-based study has its own objectives and uses different assumptions. For example, the MA developed "four scenarios to explore plausible futures for ecosystems and human well-being based on different assumptions about driving forces of change and their possible interactions" (MA 2005). The MA scenarios were developed to identify the unpredictable features of change in drivers and ecosystem services, not merely as future predictions (MA 2005).

There is a broad classification of scenario design: whether the scenario is a forecast or a backcast. Both procedures have similar objectives - a future state and a path by which to reach it - but the process for generating that scenario is very different:

- The forecast approach starts with the current situation, identifies paths into the future and chooses one path for the scenario.

- The backcast approach starts with the current situation and a desirable future state based on defined parameters, and then deduces possible future paths.

Since a backcast involves some judgment about a desirable future state, it is called a normative scenario, while forecast scenarios are called descriptive or exploratory scenarios. In other words, scenarios can be developed in an exploratory fashion, i.e., as interim developments that are not constrained by a predetermined end vision, or they can be developed in a backcasting fashion, i.e., as interim developments that are driven in part by the desire to reach such a vision.

The transition to sustainability is a long-term journey that must be addressed now. The backcasting approach - i.e., envisioning a sustainable society based on defined parameters and designing strategies and identifying paths towards that end - is the approach that most ably serves the sustainability goal.

Analysis of scenarios, visions and roadmap strategies

Table 1 summarizes how major scenario-based studies address the carrying capacity concept. The table compares visions of a future society in terms of five global challenges. Each challenge can be described by the following four criteria: (1) concept of carrying capacity, (2) indicators and targets, (3) major driving force and (4) policies and commitment. The first four challenges in the table cover the key issue domains of global warming, ecosystems and energy and material resource production and consumption, while the challenge "plural bottom-line approach on industry or society level" integrates trans-boundary and multifaceted attempts to build sustainable visions or scenarios, such as the Japan Sustainable Society Energy Vision - Triple 50 (Sustainable Society Research Group 2005), Japan Vision 2050 (Science Council of Japan 2005), Japan Low Carbon Society 2050 (Fujino 2005) and Switzerland's 2000 Watt per capita Society (Jochem et al. 2002; Jochem 2004). The details of these and other sustainability visions are shown in Table 2. All these attempts seem to have common features:

1. The scenario studies seek to ensure sustainable development by decoupling economic development from environmental pressure.

2. The scenario studies address the driving forces that impact negatively on sustainability and the intervening strategies to reduce them. The studies adopt D-P-S-R (driving force, pressure, state and response) (OECD 1993; European Environment Agency 1999) as a common framework. In order to propose correspondent policies and measures that will affect economic activities and daily lives, it is imperative to assess innovative technology and to design institutional settings and processes that can enable the social application and diffusion of this technology.

3. The goals or targets for a sustainable future are stated clearly in the scenario studies. Since those goals cannot be achieved with current trends (the bottom-up approach), most of the studies adopt the backcasting approach. Dynamic scenarios play an important role in dealing with the wide gap that exists between the future and present.

4. Understanding of and respect for cultural diversity are fundamental to achieving a sustainability transition (UN 2002). In this regard, these studies 


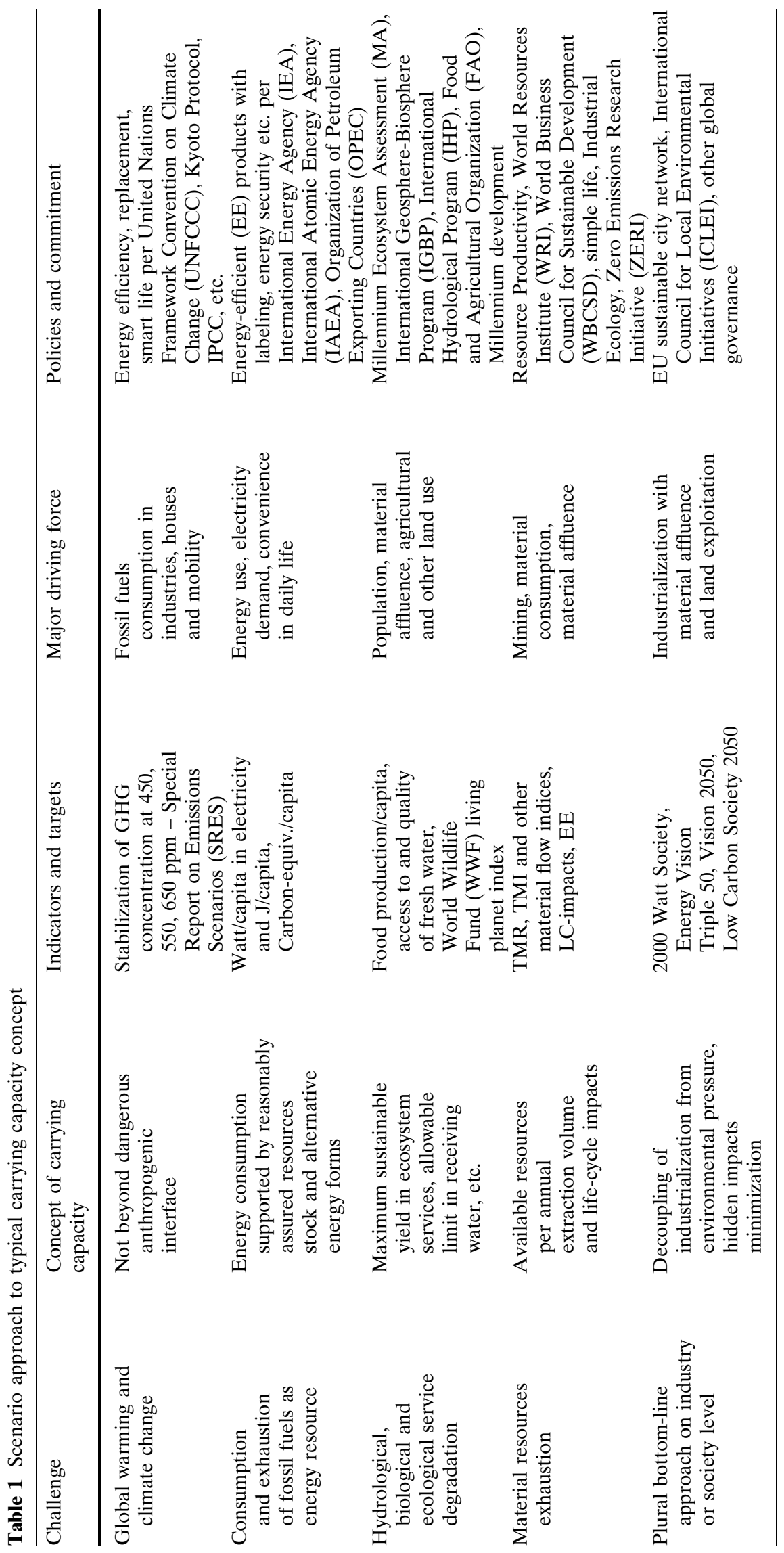




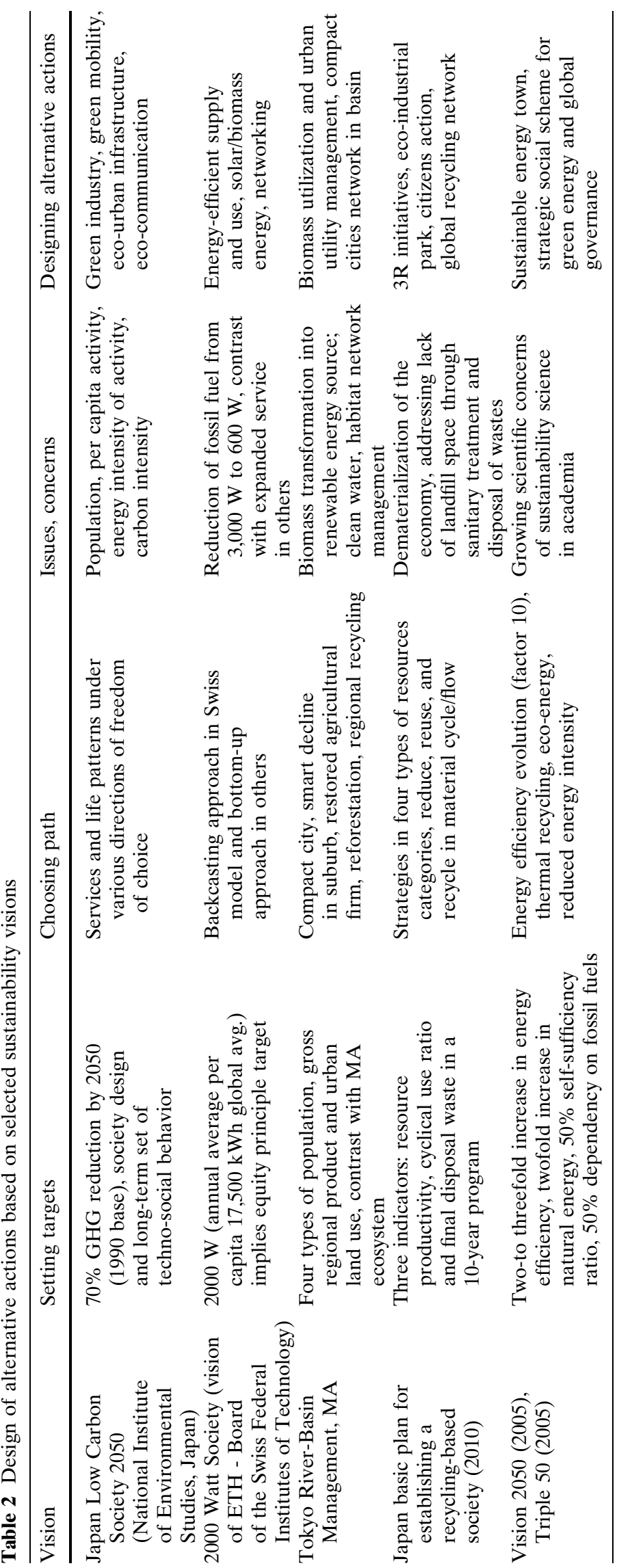


assume a strong global cultural stability in their scenario designs. However, we may face adverse consequences of globalization, such as massive migration to the developed world and an increasing economic, cultural and technological gap between developed and developing nations (Chirot 2001), or international conflicts (Huntington 1996), which could affect the results of these scenario analyses.

5. As a key support for science and technology in the environmental area, the Japanese Government has decided to continue its Science and Technology Basic Plan into a third phase addressing such issues as global warming, establishing a closed-loop economy and environmental risk. In the field of environmental risk, the macro systems approach to scenario studies is not fully emphasized because of higher public concern about individual toxicity or individual impacts. In the other fields, since individual effects are easier to determine, the task is to promote their integration through the use of comprehensive indicators.

6. It is possible to show increases in environmental sustainability patterns using a few indicators for such issues as global warming and energy consumption. For example, in order to realize a pathway to environmental sustainability, it is necessary to reduce fossil fuel consumption and $\mathrm{CO}_{2}$ emissions by $50-70 \%$ by the year 2050 (Matsuoka 2005).

7. The Swiss government takes a similar approach in the search for sustainability with the 2000 Watt per capita Society proposal, which focuses on individual $\mathrm{CO}_{2}$ emissions. With efforts like these, developed countries are addressing their share of responsibility and, at the same time, demonstrating the necessity of reducing environmental pressures in the long term, rather than envisioning a desirable future lifestyle or society.

A common point addressed by these selected sustainability visions in Japan and abroad and the design of alternative actions based on these visions is the urgent need to reduce resource consumption while maintaining high living standards. The Japanese visions, for instance, are related to promoting sustainable resource and waste management that includes improvements in resource productivity, energy efficiency and consumption, as well as streamlined urban land use and ecosystem management with projects such as the Tokyo River-Basin Management (Fujita and Morioka 2003). Even though the four visions related to Japan were designed based on domestic issues, they could be applied in other areas because they address the same challenges all industrial nations face. The 2000 Watt Society vision is an ambitious project of the Swiss government that could also be applied in other societies. It fosters a drastic reduction in per-capita energy consumption through research and innovation in key technological areas and changes in lifestyles, especially in the developed world. Foundational technologies such as information and communication technology (ICT) should also be recognized as a source of potential system shift. Allenby and Roitz (2003), for instance, argue that network-centric organizations are more flexible, more efficient and more productive in terms of labor and capital. The shifting-away of firms from physical assets (buildings, offices, etc.) to knowledge systems and networks will yield both economic and environmental benefits (Allenby and Roitz 2005).

\section{Innovation systems and technology transition management}

Incremental policies are not sufficient to address the vast and complex societal problems we face nowadays. Energy supply, transport, agriculture and other problems require a new approach towards societal change. Much of the effort to find a pathway towards a sustainability transition has been focused on product and process innovations. Energy-efficient and cleaner technologies, processes and products are examples of such innovations. These system optimizations have led us - and can continue to do so - to substantial improvements in eco-efficiency. It is argued that a factor 2 improvement is possible with these incremental innovations (Geels 2005). However, a transition towards sustainability requires a larger, more integral innovation system. Such a transition requires, for instance, changes from one energy system to another.

Innovation systems are defined as large-scale transformations in the way societal functions such as transportation, communication, housing, among others are fulfilled (Geels 2004). Technology has a central role in fulfilling these functions. In this sense, an innovation system can be understood as a change of a socio-technical system. Geels (2005) also argues that an innovation system has three aspects:

- Technological substitution, which comprises the emergence of new technologies, diffusion of new technologies and replacement of old technologies;

- Co-evolution, which involves changes in elements such as user practices, regulations, industrial networks, infrastructure and cultural meaning; 
- Emergences of new functionalities related to particular technical properties of radical innovations.

Innovation systems require us to understand the principles of transition or transformation processes that a society undergoes. A transition can be defined as a long-term process of change whereby society, or a complex sub-system of society, transforms fundamentally. A societal transition is the result of co-evolution between technological, economical, ecological, cultural and institutional developments on different scale levels (Rotmans et al. 2000).

Innovation system elements towards sustainability

Innovation systems are also defined as systemic, dynamic and non-linear processes that involve uncertainties and interactions between technological and institutional factors (Rip and Kemp 1998). They are systemic because they involve multi-actor feedback and interactions involving both market and non-market transactions, such as knowledge flow (Foxon et al. 2004). They are dynamic because technological and institutional changes occur at different levels and time scales. Individual technologies change rapidly, while technological systems change slowly. Innovation systems are non-linear because systems show increasing returns to their adoption in such a way that small changes in initial conditions result in different outcomes. Finally, innovation processes are uncertain because future technological and market opportunities cannot be known (Foxon et al. 2004). Since the transition-towards-sustainability approach involves a drastic transformation of societal functions, it can benefit from elements of the innovation system approach.

\section{Transition management}

Transition management is necessary to propel effective innovation systems. A transition is a gradual process that usually takes one or two generations. Transition management is based on a multi-level and multi-phase perspective of social change processes (Kemp 1994). Geels (2002) argues that three levels of change are distinguishable in a technology transition:

- Micro-level: practical experimentation and demonstration is nurtured in niche markets to promote technological innovation and establish the base for further commercialization.

- Meso-level: where successful innovations gradually influence the foundations of the societal system based on infrastructural configuration, institutional arrangements and company behavior until a new regime emerges. This is the tactical level where selection of the best innovations takes place.

- Macro-level: where long-term strategies are addressed. Societies define their basic norms and values, their broader ambitions and political goals. This is the level where selection mechanisms are formed and propagated.

\section{Technology innovation systems}

Foxon et al. (2005) distinguish five stages in the commercial maturity or spread of a technology: research and development (R\&D), demonstration, pre-commercial, supported commercial and fully commercial. In this process the knowledge flows in both directions, allowing a fruitful interaction between technology creators and technology users. With this framework it is possible to reinforce the conventional drivers of technology push, from R\&D, and market pull, from customer demand. This categorization also allows us to identify the stages at which innovation system failures may be occurring and, at the same time, promote the dissemination of sustainability-oriented technologies by improving the flow between those stages.

\section{Lock-in in technology development}

Technologies and technological systems follow specific paths that are difficult and costly to escape, a phenomenon known as technological lock-in. There are two explanations for the existence of technological lock-in. Dosi (1982) argued that the nature and direction of technological progress is strongly shaped by the cognitive framework of actors. He used the term "technological paradigm" to refer to the existence of certain rules, heuristics or principles that define the boundaries of thought and action by members of the technological community (engineers, firms, technology institutes, etc.). The second explanation for lock-in draws from the idea of increasing returns to adoption: positive feedback mechanisms (economies of scale, learning effects, adaptive expectations and network or co-ordination effects) that function to increase the attractiveness of adopting a particular technology the more it is adopted. David (1985) and Arthur (1989) explained that in a situation where two or more technologies are competing for market share, the presence of increasing returns implies that the option which secures an initial lead in adoption may eventually go on to dominate the market. These returns can result in 
technological lock-in, where incumbent technologies create barriers to the adoption of new technologies. Furthermore, institutions that support technological systems exhibit similar types of increasing returns (Unruh 2000; Pierson 2000). It has been argued that this interaction, or co-evolution, between technological and institutional systems can reinforce the lock-in of techno-institutional systems, leading, for example, to the carbon lock-in of fossil fuel-based energy systems (Unruh 2000).

\section{Innovation promotion}

In their promotion of innovation systems, Johnson and Jacobsson (2001) argue that an innovation system serves five functions: to create and diffuse new knowledge; to guide the direction of the search process among users and suppliers of technology; to supply resources, including capital and competencies; to create positive external economies through the exchange of information, knowledge and visions; and to facilitate the formation of markets. There are, however, some mechanisms that could induce or block these innovations. Incentive mechanisms include government policy, facilitation of firm entry, and feedback from market formation. At the same time, obstructing mechanisms such as uncertainty, lack of political support, poor connectivity of networks, and opposing behavior of established firms could affect the smooth development of technology innovation.

\section{Decision-making under uncertainty}

Economic actors such as individuals, firms or governments are limited in their ability to gather and process information for decision-making purposes. Since the future is uncertain, knowledge and learning processes are the keys to the innovation process. Combinations of existing knowledge account for most innovation as a result of various forms of learning: learning-by-doing (Arrow 1962), learning-by-using (Rosenberg 1982) and learning-by-interacting (Lundvall 1992). Since innovations are characterized by uncertainty about future markets, technologies and policies, it follows that firms' and investors' expectations of these future conditions are a crucial influence on their decisions about which technologies to invest in and develop (Rosenberg 1982; MacKenzie 1992).

In sum, if we consider and address effectively all of the elements of system innovation towards a sustainability transition, then it will be possible to achieve the desired societal development. Allowing the perpetua- tion of business as usual will eventually cause system lock-in or, worse, system failure (Fig. 2).

Transition management in practice: technology innovation management

The creation and promotion of science and technology relies on a system that supports the ability of a country to innovate. Innovation and technology are the pillars that support the transformation of countries from reliance on the exploitation of natural resources to technological innovation as the basis for development (Calestous and Lee 2005). With the globalization of science and technology (S\&T), R\&D and ICT, we can improve and accelerate technology innovations towards a sustainability transition.

A technology innovation system must involve all of the relevant factors that influence its development, diffusion and use: research and technology capacity on the supply side, and social and human capital and the absorptive capacity of the market on the demand side. The interactions and relations between the main players in a technology innovation system are vital to envisioning a long-term innovative performance. At the same time, we must address the challenge of how to rapidly bridge the gap between knowledge, technology and the market as well as to achieve the diffusion of sustainability-oriented innovations for the common benefit between demand pull (demand from society) and technology push (desire from the S\&T community to link research with industry and the know-how to achieve it).

An integral technology innovation system

Innovation systems bridge the gap between knowledge and its intrinsic technological possibilities and at the same time match these technological possibilities

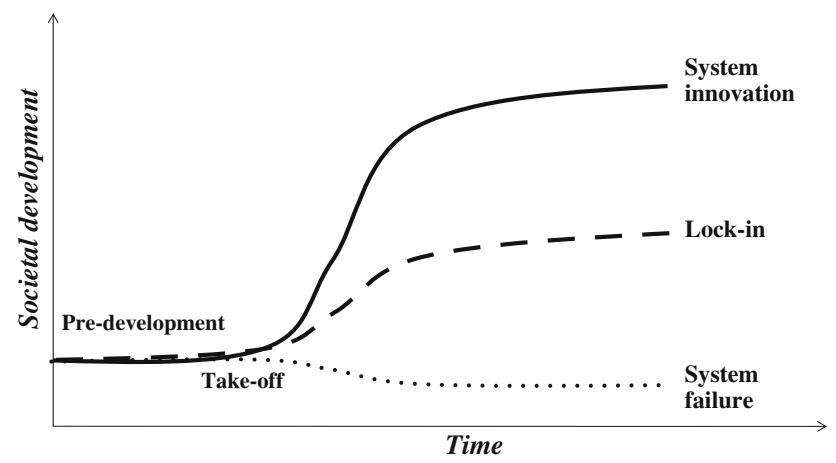

Fig. 2 Types of system states based on technology development outcomes 
with market needs. Since a sustainability transition demands innovation in the current socio-economic system, it is important to design an integral innovation system that can address this demand. It is necessary to recognize, however, that the concept of sustainable development has a strong normative orientation and that different cultures may interpret the concept differently according to their values and lifestyles. This cultural diversity makes socio-economic system innovation difficult.

Innovations greatly depend upon local capabilities and needs, existing designs and complementary technologies. The IPCC (2000) summarized some general features of this complex innovation process as follows:

- The process is fundamentally uncertain: outcomes cannot be predicted.

- Innovation draws on underlying scientific or other knowledge.

- Some kind of search or experimentation process is usually involved.

- Many innovations depend on the exploitation of "tacit knowledge" obtained through "learning by doing" or experience.

- Technological change is a cumulative process and depends on the history of the individual or organization involved.

Transition management, which is vital to propel innovation, orients existing dynamics through its focus on sustainability visions. It aims to overcome the conflict between long-term ambitions and short-term concerns so as to eventually provide environmental, economic and social benefits. Elements of transition management include the formulation of transition goals and the use of process management based on a philosophy of learning-by-doing and doing-by-learning. The goals and the policies/strategies to achieve them are constantly assessed and adjusted.

Kemp and Loorbach (2005) argue that the key elements of transition management are:

- Long-term approach as a framework for short-term policy;

- Backcasting: the setting of short-term and longerterm goals based on long-term sustainability visions and short-term possibilities;

- Multi-domain and multi-level thinking: analysis of the interactions between different domains and levels;

- A focus on practical learning philosophy;

- An orientation towards system innovation.

Based on these past studies, we assume that the management of technology transition towards sustainability is promoted through the interaction of three components: the demand side (demand pull), supply side (technology push) and institutional design, including economic and cultural settings as shown in Fig. 3. Technology roadmaps and backcasts can be categorized into normative studies which "aim to produce a picture of a desired future, or to elaborate possible routes towards such a future", while descriptive studies like scenarios describe plausible futures based on changes in trends and drivers (McDowall and Eames 2004). The backcast-based transition scenario which entails knowledge and value transformation plays the role of demand pull. Technology development and innovation pushes the potential to achieve sustainability. Institutional design coordinates, governs and synchronizes feedback loops between the demand pull and the technology push.
Fig. 3 Conceptual model of technology transition process and transition principles

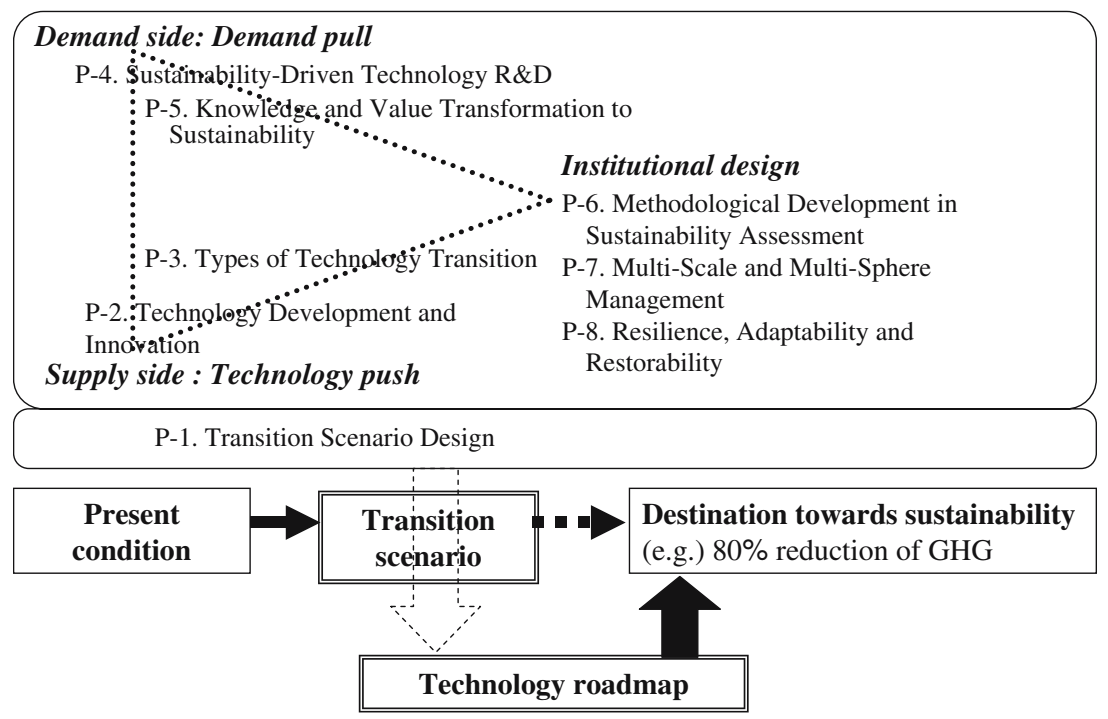




\section{Transition principles}

In order to propel the management of technology transition towards sustainability through this triangular model, we propose eight transition principles (Fig. 3, Table 3). As discussed in the previous section, designing scenarios towards a sustainable future provides the basic framework of transition (principle P-1). On the supply side, we consider technology development and innovation essential to improving sustainability (P-2), and identify six types of technology transition (P-3): Type 1: Upgrading and Upscaling, Type 2: Downscaling and Downsizing, Type 3: Replacing and Substituting, Type 4: Coupling, Combining and Synergizing, Type 5: Networking and
Linking and Type 6: Enabling Wise Management and Use. These types can be mapped using two differentiating axes. The first axis relates to whether change is promoted by the invention of technology or by the selection of technologies. The second axis concerns whether transition requires high coordination (Berkhout et al. 2004), or whether technology change is tightly or loosely coupled to the system (Perrow 1999).

The management of technology transition also acknowledges the potential of foundational technologies (nanotechnology, biotechnology, information and communication technology and cognitive science). On the one hand, the unification of science based on its unity in nature and a holistic approach could lead us to technological convergence and a more efficient societal

Table 3 Transition principles towards sustainability

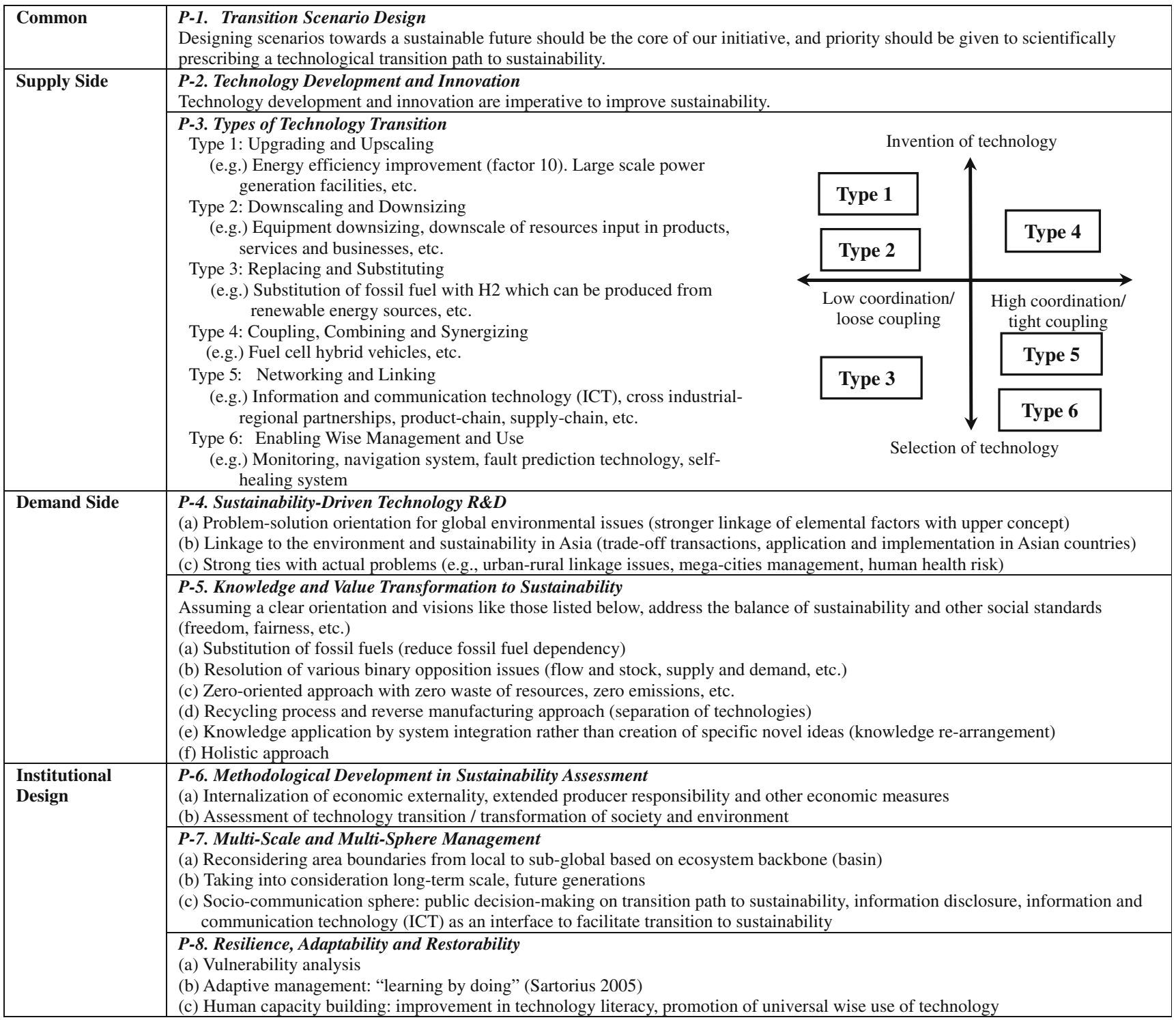


structure for reaching human goals (Roco and Bainbridge 2003). On the other hand, health and safety, environmental, ethical and societal risks or uncertainties could also arise from the use of these technologies (RS/RAE 2004).

Demand side principles emphasize sustainabilitydriven technology R\&D (P-4) and knowledge and value transformation to sustainability (P-5). Knowledge and value transformation can work as drivers of transition as well as the results of transition. The principles for institutional design relate to sustainability assessment and management. The former involves developing indicator systems for the transition of production and consumption (P-6) while taking into account uncertainty, which is not only a matter of probability distributions but also is characterized as ignorance in the face of novel events (Sartorius 2005). Reconsidering spatiotemporal scales and the socio-communication sphere is another principle of institutional design (P-7). The concept of the socio-communication interface works as a medium for the transmission and interaction of knowledge for sustainability. Moreover, a sustainable society should be resilient, adaptive and restorable in response to unpredictable future changes and events (P-8). In this sense, it requires vulnerability analysis, adaptive management (UNEP/CBD 2000) and human capacity building.

The RISS transition management approach for system innovation is based on the three components of technology push, demand pull and institutional design.
Based on these components and through future scenario design, we will propose long-term visions and mid-term strategies that will permit a smooth transition towards sustainability (Fig. 4).

Key players and their interactions in system innovation: the importance of networking and knowledge flow

The success of sustainability-oriented transition management depends strongly on the interactions and performance of the involved players. This multi-player network requires the application of systems thinking as a dynamic and non-linear process that allows knowledge flows and market transactions between users, producers and developers. It also requires the creation of windows of opportunities by supporting technology and market niches, promoting options to overcome technology lock-in and implementing the "substitution principle". It requires enhancing stakeholder participation by involving end-users in policy processes and design outcomes while promoting upstream solutions. It requires integrated measures that include marketbased instruments, market development measures, support for R\&D and demonstration and information networks. Finally, it requires a continuous and dynamic knowledge flow among the players of the sustainability network. In this sense, sustainability communication is vital for the promotion of a smooth and clear transmission of the benefits of sustainability-oriented innovations to society. Sustainability communication in this
Fig. 4 RISS system innovation approach towards a sustainability transition

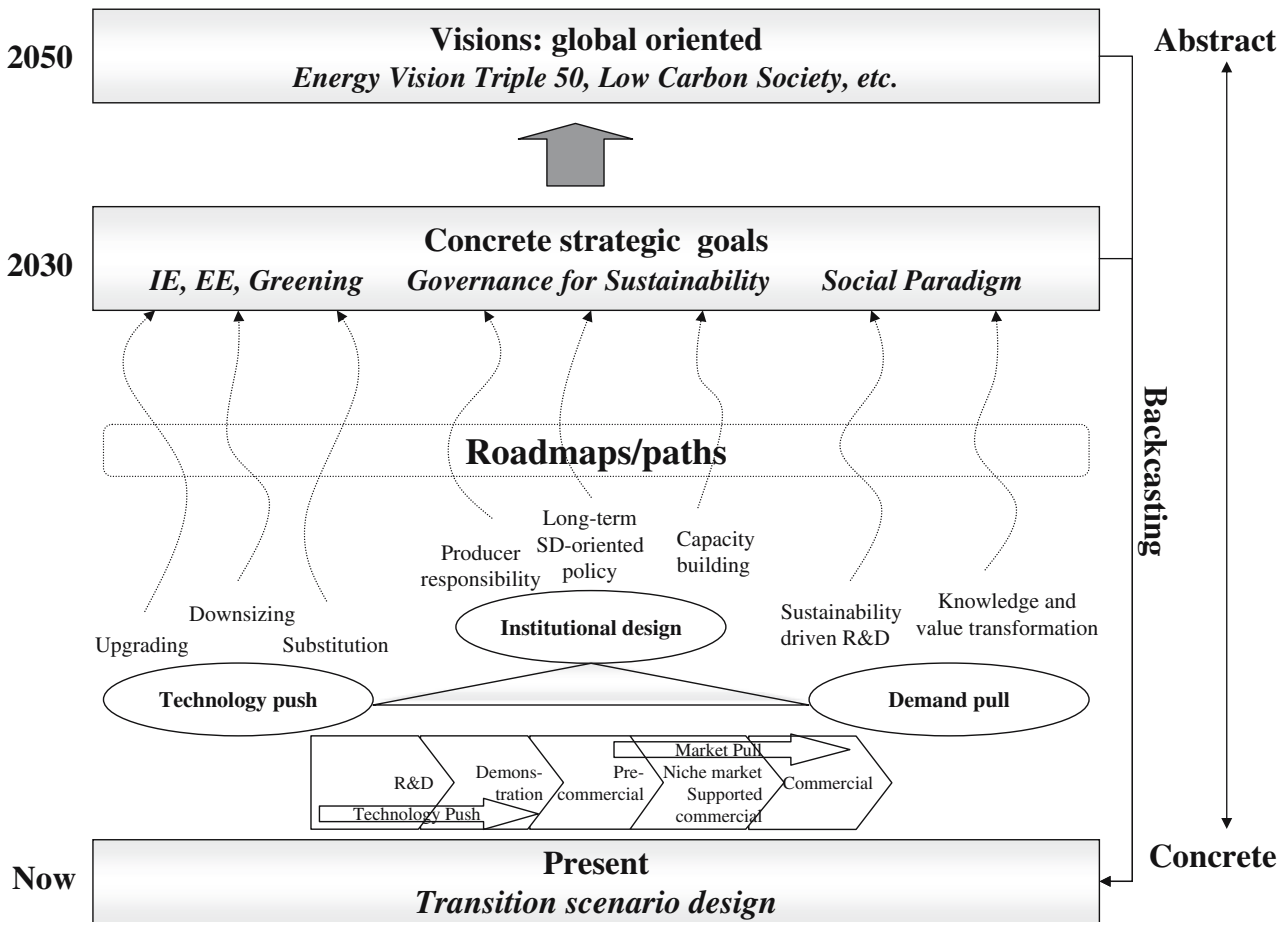


case implies communication to link our efforts towards sustainability not only through environmental reports and other means by producers, $R \& D$ networks and public authorities, but also via internal communication within each player group or organization. Governments, societal groups and other institutions have a central role to play in channeling the needs of both technology push and demand pull actors and in transforming these needs into integrated policy according to the carrying capacity of the planet (Fig. 5).

\section{The Research Institute for Sustainability Science}

In order to promote a dynamic system innovation towards sustainability, Osaka University RISS seeks to devise a self-reforming research system for the existing technological paradigm through active social interaction. The shift to a more sustainable path requires that human beings reconsider the current technological paradigm, which tends to be blind to other technological possibilities (Dosi 1982). A technological paradigm can result in technological lock-in, where incumbent technologies create barriers to the adoption of new technologies that could be environmentally friendlier. Similarly, consumption is usually shaped by certain behavior patterns that are very difficult to change. Thus, the shift to a sustainability transition must involve not only new technological possibilities but also new consumption patterns. A new paradigm for sustainability should stand closer to the problemoriented approach. The tackling of problems must be future-oriented as well as global-oriented. In addressing this important issue, RISS sees its main responsibilities as follows:

1) Construct an industrial and social management model that envisages social sustainability through changes in consumption patterns and lifestyles and the future science and technology to support that sustainability.

2) Conduct research to design transition scenarios towards a sustainable society formulated through the design of appropriate roles and the functional development of environmentally friendly basic technologies with high eco-efficiency.

3) Design a R\&D strategy which sets out, manages and addresses the technological challenges in achieving sustainability as well as related institutional issues and which provides a set of sustainability indicators, including economic/ organizational factors.

4) Design and establish the Sustainability Science and Technology Development Laboratories (SSTLabs), to be organized with institutional members from among the universities and cooperating research institutes of the IR3S, and create innovative sustainable social technology through their activities.

This initiative focuses on designing an industrial transformation that will implement natural resource conservation and pollution prevention with eco-industrial technologies. As shown in Fig. 6, industry in this case implies a critical medium that interconnects technology with society. Since the International $\mathrm{Hu}-$ man Dimensions Program on Global Environmental Change (IHDP) has been working on industrial transformation (IHDP-IT) as one of four international science projects (IHDP-IT 1999), RISS will seek further development in this field through research in energy, bio(-refinery/material) and design for production and consumption as three major research arenas for sustainable industrial ecology. RISS will organize and manage three focal $R \& D$ laboratories in collaboration with the industrial sector:
Fig. 5 Multi-player networks and their interactions towards a sustainability transition

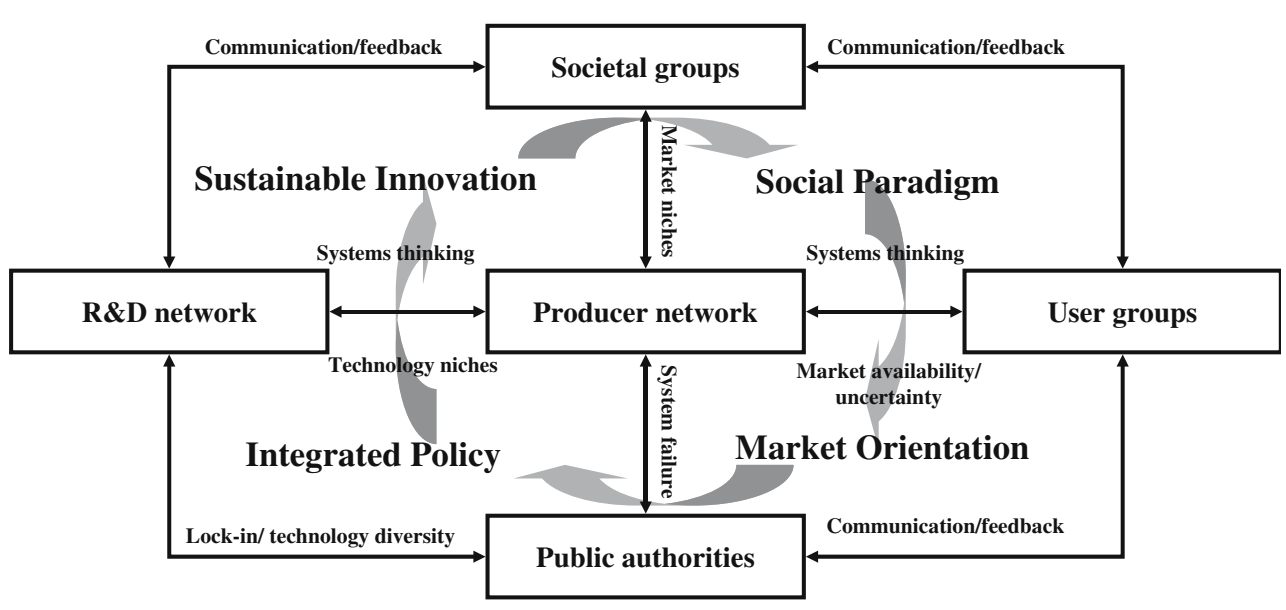


Fig. 6 RISS integral system: technology development and social system design
Comprehension and creation of the wisdom

(knowledge) of sustainability

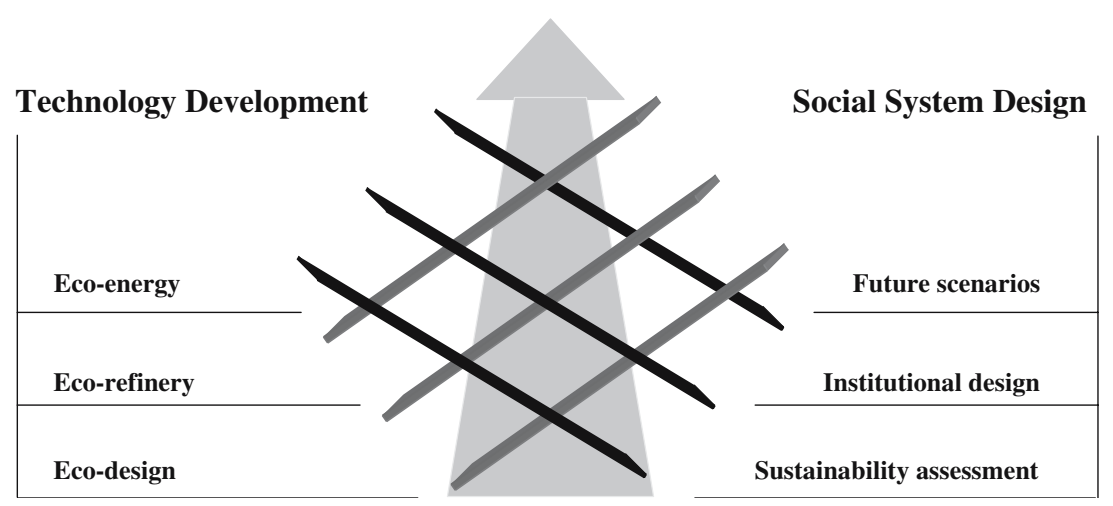

1) Eco-energy: development of innovative energy conversion and storage technologies (light, heat and electricity), including thermo-electric materials and hydrogen storage to substitute fossil fuel; development and practical study of new energy conversion devices; promotion of eco-energy network systems.

2) Eco-refinery: technology system of eco-materials, eco-biological and biochemical technologies (gasification, pyrolysis, etc.); food production and energy systems based on biomass refinery.

3) Eco-design: technology design system based on a sustainable society; environmentally friendly design of end-use products and industrial processes.

Since the development of eco-industrial technology must be closely linked with societal change, we also propose the development of social system innovations through the following three areas:

4) Future scenarios: scenario design with sustainability visions, strategic goals and accompanying roadmaps, knowledge science and ontological studies to understand the complex systems in the human-environment sphere.

5) Institutional design: environmentally-oriented social systems, institutional and legal frameworks to promote eco-industries, promotion of environmental initiatives.

6) Sustainability assessment: analysis and solution of technological problems within the frame of sustainability assessment indicators, sustainabilitybased technology management.

Finally, RISS proposes the conceptual analysis of sustainability science making use of knowledge science methodology including ontological science. Through this process we hope to contribute to the establishment of a common base for sustainability science.

Framework and functions of RISS

The Osaka University RISS will be composed of the Design House for Sustainability Science (Design House) and the Sustainability Science and Technology Development Laboratories (SST-Labs). The Design House is the core of the institute and is composed of two units: the Scenario Design Unit for a Sustainable Industrial Society (Scenario Unit) and the Strategy Unit for Science and Technology Development (Strategy Unit). The Design House is responsible for creating new disciplines and knowledge of humanenvironment interactions. Based on the technology development goals set by the Design House, several SST-Labs will be established to perform the related R\&D.

\section{Design House}

Newman (2005) summarized "four core processes that build on each other to provide a course of action that leads toward a state of higher sustainability" based on the Natural Step concept (Nattrass and Altomare 1999). The steps are to (1) understand the principle of sustainability, (2) locate unsustainable processes and determine the gain in changing them, (3) form a vision of how to change them by "backcasting" from the final goal and (4) identify a series of paths leading to that goal, then pick a path. We will attempt to follow these steps while acknowledging that it is difficult to control the evolutionary paths of complex systems because, among other reasons, technological evolution is particularly affected by lock-in and path dependence (Sartorius 2006). 
The Design House will navigate and coordinate these four processes with its two functional units, the Scenario Unit and the Strategy Unit, working on steps (3) and (4) respectively, while the Design House as a whole will focus on steps (1) and (2) as its main agenda. In other words, while the Scenario Unit will mainly focus on making future sustainable society projections and on setting technology development targets, the Strategy Unit will handle the management of $R \& D$ with a focus on the scientific features of the targeted technologies.

\section{SST-Labs}

This project will begin with the selection of the most appropriate research seeds based on the key technology developments proposed by the Design House. The SST-Labs will be organized to carry out development research that specifically follows the sustainability technology roadmap based on these seeds.

The Design House approach to scenario design and roadmap strategies

The Scenario Unit will formulate a comprehensive vision of the mid-future technological transition to sustainability and will organize and manage the research labs to meet concrete R\&D targets. In the scenariomaking, Japan will serve as a model for developed nations, and Asian countries where rapid economic growth is forecast will serve as models for developing nations. We will conceive plans for a sustainable industrial society system for Asia, where the population is estimated to reach approximately four billion by 2050, and examine transition scenarios leading in this direction. Various scenarios will be constructed by changing the target regions and time periods and estimating different types of driving forces and states of the environment. In our research, high priority will be given to designing scenarios for ASEAN nations plus Japan-China-Korea and India.

Another objective of the Scenario Unit is to develop a new theory or model that will enable us to measure sustainability and to design a future industrial society despite the uncertainty inherent in sustainability science. This model will be based on the innovation system explained in the section Innovation systems and technology transition management. Environmental sustainability can be determined by measuring the soundness of coupled human-environment systems, the level of reduction of human pressure on the environment and the ability to take care of the environment under the driving force, pressure, state and response
(D-P-S-R) framework. The Scenario Unit will work on translating the sustainability concept into a more realistic context for industrial society by developing mid-21st century scenarios in Asia. These scenarios will describe (1) supply and treatment infrastructures for material resources, energy and food, (2) urban systems and spatial composition of industrial cities and (3) the closed-loop industrial system. Each scenario will be drawn up with a different form, pattern, population density, production, consumption and other human activities, and will take into account anticipated widespread repercussions and tradeoffs between regional environments and highly efficient tools, devices and infrastructures in industrial systems. We will also develop analytical tools to assess and simulate the effects of each scenario on the environment and human quality of life (QOL). These tools are expected to contribute to quantifying the requirements for sustainability in Asia.

The economic value of the environment should be reflected in the design of these scenarios. We will therefore develop tools for measuring and predicting the effects of macro-systems design in order to balance environmental conservation and economic growth. At the same time, we will develop a scheme to create socio-economic incentives for technology development by attributing contributions (property rights) to the developers of innovative technologies for global warming prevention.

Figure 7 illustrates a conceptual process model of technology transition and the role of the Design House within this process. The Scenario Unit, with its future sustainable society projections and technology development targets, and the Strategy Unit, with its technology roadmaps towards those targets, will constitute the demand pull necessary to maintain dynamic technology management. In this process, the $R \& D$ of Osaka University RISS as well as the contributions of the other IR3S universities and research institutes will constitute the technology push aspect by navigating through the proposed six types of technology transition. In a concerted effort of both technology push and demand pull, we will design and improve technology management based on the continuous change, innovation and interaction of $R \& D$ towards a transition to sustainability.

The innovation and evolution process of the photovoltaic (PV) cell is a clear example of how a technology has to go through the different types of technology transition until it reaches a level of maturity and enjoys widespread application, as shown in Fig. 8. Since the discovery of the photoelectric effect and the invention of the semiconductor, the PV cell has passed 
Fig. 7 Conceptual process model of technology transition to sustainability

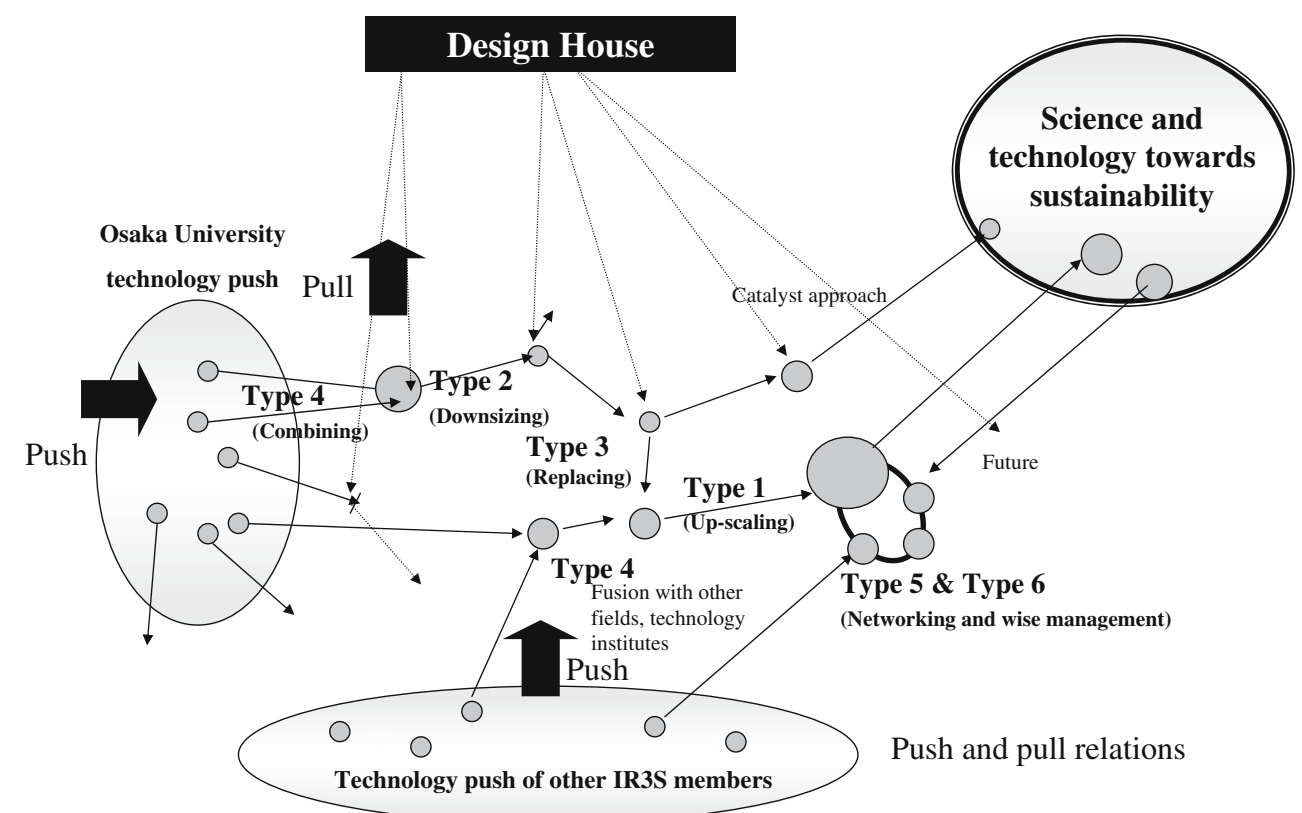

Slow decrease in cost of silicon solar cell, tightness of silicon supply/demand, slowdown of leading policies
Invention of semiconductor, discovery of the photoelectric effect, prototype of silicon PV cell (1954)

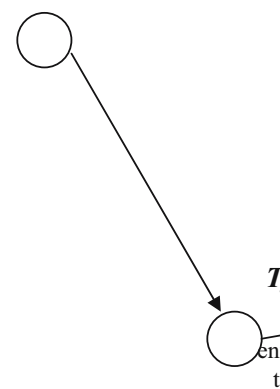

Application in space missions (1958 Vanguard 1; in the 60 s it became basic for space missions)

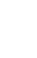

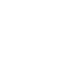

Oil shock

Positions as an oil alternative energy source, with high efficiency and low conversion costs (sunshine project: solar, geothermal, coal, hydrogen)

Type 3

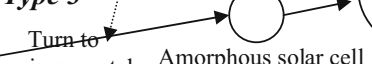

Amorphous solar cell (1976-79), PV cell marketing

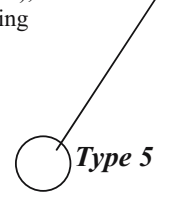

Power systems-storagebuilding materials technology

Fig. 8 The innovation process of the photovoltaic cell

through five of the technology transition types proposed in this article and now has many and varied applications for the benefit of everyone.

In the context of a transition to sustainability, major differences between modern (20th-century) science and sustainability science are summarized in Table 4.
These differences are outlined according to the eight principles proposed in this article to be associated with the interaction of demand pull (demand side), technology pull (supply side) and institutional design. Both types of science evolve within the change, innovation and interaction framework, but since sustainability 
Table 4 Comparison of modern science and sustainability science

\begin{tabular}{|c|c|c|c|}
\hline \multicolumn{2}{|c|}{ Dimension of principle } & \multirow{2}{*}{$\begin{array}{l}\text { Modern science } \\
\text { Linear trend prediction }\end{array}$} & \multirow{2}{*}{$\begin{array}{l}\text { Sustainability science } \\
\text { Plural plausible future scenarios } \\
\text { and transition roadmaps, } \\
\text { self-control, subjective and } \\
\text { objective realization, decoupling } \\
\text { of economic growth from } \\
\text { environmental degradation }\end{array}$} \\
\hline Common & P-1. Transition scenario design & & \\
\hline \multirow[t]{2}{*}{ Supply side } & $\begin{array}{l}\text { P-2. Technology development } \\
\text { and innovation }\end{array}$ & $\begin{array}{l}\text { Techno-centric approach, } \\
\text { linear model of technology } \\
\text { development }\end{array}$ & $\begin{array}{l}\text { Contingent on essentiality, } \\
\text { extensibility, and reach ability } \\
\text { of technology; "Mode 2" } \\
\text { R\&D based on social demand }\end{array}$ \\
\hline & $\begin{array}{l}\text { P-3. Types of technology } \\
\text { transition }\end{array}$ & $\begin{array}{l}\text { Technology management } \\
\text { based on economic efficiency } \\
\text { and marketability }\end{array}$ & $\begin{array}{l}\text { Technology transition management } \\
\text { for sustainability including } \\
\text { institutional design, decision-making, } \\
\text { and monitoring overall effects } \\
\text { and tradeoffs }\end{array}$ \\
\hline \multirow[t]{2}{*}{ Demand side } & $\begin{array}{l}\text { P-4. Sustainability-driven } \\
\text { technology R\&D }\end{array}$ & $\begin{array}{l}\text { Technology R\&D to fulfill } \\
\text { economic development }\end{array}$ & $\begin{array}{l}\text { Leading and guiding technology } \\
\text { R\&D based on the principles } \\
\text { of transition towards sustainability, } \\
\text { paradigm shift from fossil fuel society }\end{array}$ \\
\hline & $\begin{array}{l}\mathrm{P}-5 . \text { Knowledge and value } \\
\text { transformation } \\
\text { to sustainability }\end{array}$ & $\begin{array}{l}\text { Specialization (foxhole) } \\
\text { technique-oriented }\end{array}$ & $\begin{array}{l}\text { Knowledge and value transformation: } \\
\text { integration, trans-disciplinary, } \\
\text { problem-solving approach, ontology } \\
\text { assisted ICT, dynamic sustainability } \\
\text { (Newman 2005) }\end{array}$ \\
\hline \multirow[t]{3}{*}{$\begin{array}{l}\text { Institutional } \\
\text { design }\end{array}$} & $\begin{array}{l}\text { P-6. Methodological development } \\
\text { in sustainability assessment }\end{array}$ & $\begin{array}{l}\text { Environmental impact } \\
\text { assessment (individual } \\
\text { project-based, sometimes } \\
\text { reactive) }\end{array}$ & $\begin{array}{l}\text { Development and application of } \\
\text { sustainability assessment: } \\
\text { vulnerability assessment, } \\
\text { carrying capacity assessment, } \\
\text { environmental efficiency } \\
\text { assessment, dynamic LCA, etc. }\end{array}$ \\
\hline & $\begin{array}{l}\text { P-7. Multi-scale and multi-sphere } \\
\text { management }\end{array}$ & $\begin{array}{l}\text { Optimization of single } \\
\text { indicator based on } \\
\text { short-term vision }\end{array}$ & $\begin{array}{l}\text { Multi-purpose/problem approach } \\
\text { based on mid- to long-term vision }\end{array}$ \\
\hline & $\begin{array}{l}\text { P-8. Resilience, adaptability } \\
\text { and restorability }\end{array}$ & Low & $\begin{array}{l}\text { High: systems approach to } \\
\text { strengthen resilience, } \\
\text { adaptability and restorability }\end{array}$ \\
\hline
\end{tabular}

science is shaped by the final goal of sustainable development, its management and development are more ambitious. Rather than follow the linear model and solely economic orientation of modern science, sustainability science undergoes a continuous process of learning and evolution that is nurtured by perpetual interaction with the needs of the human-environment system - a process that will enable us to reach the ultimate goal of a sustainable industrial society.

\section{Conclusion}

While it is widely known that sustainable development is the only sound and viable pathway for humankind's future, its attainment remains elusive despite intensive efforts and some successes. This article has laid out the initiative of the RISS to contribute to global sustainability through reform and streamlining of the current technological paradigm. This reform is based on a future-oriented and global approach. In this initiative, industry plays a critical role as a link between technology and society. This article also proposed a technology transition towards sustainability through the interaction of technology push (supply side), demand pull (demand side) and institutional design. The proposal is based on eight principles that will enable a smooth transition towards sustainability. Of these principles, that of technology transition types plays a key role because it introduces six types of technology which we believe are fundamental to the achievement of sustainability. This article also introduced the seeds for development of a new model that could allow us to quantify progress in sustainability. For this model we proposed that environmental sustainability can be determined by measuring the soundness of coupled human-environment systems, the reduction level of human pressure on the environment and the ability to 
take care of the environment under the D-P-S-R framework. Based on this model and considering such factors as population density, production and consumption and infrastructures in the industrial system, it is possible to design a more realistic and sustainabilityoriented scenario for a future industrial society. Finally, we believe that the RISS initiative can make an important contribution to the goal of sustainability and we will pursue its development to that end.

Through the introduction of an innovation system that seeks to streamline the current technological paradigm and of a technology transition model, this article has offered a framework for the transition to sustainability. We believe that efforts like IR3S are important to ensure for ourselves and future generations a planet that will provide us with the natural capital essential for our development. While this initiative should be an important step in the journey towards sustainability, more needs to be done in this field. The design of a standardized model that could enable us to quantify progress towards sustainability is crucial for this journey. We need tools that will let us measure the different sustainability initiatives and help us concentrate our efforts and resources on the development of the science and technology that will contribute most to the goal of sustainability.

Acknowledgements The authors would like to thank Professor Masao Toyoda, Professor Riichiro Mizoguchi, Professor Tatsuyoshi Saijo, Professor Yasuo Takahashi, Professor Masahito Taya, Professor Michihiko Ike, Associate Professor Yoshiyuki Shimoda, and the other members of the RISS Working Group for their valuable comments and suggestions for this article.

\section{References}

Allenby B, Roitz J (2003) Implementing the knowledge economy: the theory and practice of telework. Batten Institute Working Paper, Darden Graduate School of Business, University of Virginia, Charlottesville, Va.

Allenby B, Roitz J (2005) Building the resilient firm: the new challenge to EHS organizations. Environ Qual Manage 5:27-36

Arrow K (1962) The economic implications of learning by doing. Rev Econ Stud 29:155-173

Arthur WB (1989) Competing technologies, increasing returns, and lock-in by historical events. Econ J 99:116-131

Berkhout F, Smith A, Stirling A (2004) Socio-technological regimes and transition contexts. In: Bolie E, Frank WG, Ken $G$ (eds) System innovation and the transition to sustainability. Edward Elgar Publ, Cheltenham, UK, pp 48-75

Borjeson L, Hojer M, Dreborg KH, Ekvall T, Finnveden G (2006) Scenario types and techniques: towards a user's guide. Futures (in press)

Bush V (1945) Science, the endless frontier: a report to the president on a program for postwar scientific research (reprinted 1960). National Science Foundation, Washington D.C.
Calestous J, Lee Y (2005) Innovation: applying knowledge in development. UN Millennium Project, Task Force on Science, Technology, and Innovation

Chirot D (2001) A clash of civilizations or of paradigms? Theorizing progress and social change. Int Sociol 16:341-360

David P (1985) Clio and the economics of QWERTY. Am Econ Rev 75:332-337

Dosi G (1982) Technological paradigms and technological trajectories. Res Policy 11:147-162

European Commission (2002) Visions and roadmaps for sustainable development in a networked knowledge society. Report of a Workshop by the Presidents of the Brussels-EU Chapter of the Club of Rome and the Factor 10 Institute, European Commission Information Society Directorate General, Brussels

European Environment Agency (1999) Environmental indicators: typology and overview. European Environment Agency, Technical Report No. 25, Copenhagen

Foxon T, Pearson P, Makuch Z, Mata M (2004) Informing policy processes that promote sustainable innovation: an analytical framework and empirical methodology. STP Working Paper series number 2004/4

Foxon T, Gross R, Chase A, Howes J, Arnall A, Anderson D (2005) The UK innovation systems for new and renewable energy technologies. Energy Policy 33:2123-2137

Fujino J (2005) Development of Japan low carbon society scenarios toward 2050. Paper presented at the COP11 and COP/MOP1 side event: global challenges toward low-carbon economy, December 2005, Montreal, Canada

Fujita T, Morioka T (2003) Regional material flow analysis for environmentally sustainable basin regional management. In: Proc Indust Ecol Sustainable Future Conf. Michigan, USA

Geels F (2002) Technological transitions as evolutionary reconfiguration processes: a multi-level perspective and a casestudy. Res Policy 31:1257-1274

Geels F (2004) Understanding system innovations: a critical literature review and conceptual synthesis. In: Bolie E, Frank WG, Ken G (eds) System innovation and the transition to sustainability. Edward Elgar Publ, Cheltenham, UK, pp 1947

Geels F (2005) Technological transitions and system innovations: a co-evolutionary and socio-technical analysis. Edward Elgar Publ, Cheltenham

Huntington S (1996) The clash of civilizations and the remaking of world order. Simon \& Schuster

IHDP-IT (1999) Research approaches to support the industrial transformation science plan. Report 19, International $\mathrm{Hu}-$ man Dimensions Program on Global Environmental Change - Industrial Transformation Project, Amsterdam

IPCC (2000) Special report on emissions scenarios. Intergovernmental Panel on Climate Change. Cambridge University Press, Cambridge

Jochem E (2004) R\&D and innovation policy - preconditions for making steps towards a 2000 watt/cap society. Energy Environ 15:283-296

Jochem E, Favrat D, Hungerbühler K, Rudolph von Rohr P, Spreng D, Wokaun A, Zimmermann M (2002) Steps towards a 2000 watt society. Developing a white paper on research \& development of energy-efficient technologies. Pre-study, Final Report, CEPE Zurich

Johnson A, Jacobsson S (2001) Inducement and blocking mechanisms in the development of a new industry: the case of renewable energy technology in Sweden. In: Coombs R, Green K, Richards A, Walsh V (eds) Technology and the market: demand, users and innovation. Edward Elgar, Cheltenham, UK 
Kemp R (1994) Technology and the transition to environmental sustainability: the problem of technological regime shifts. Futures 26:1023-1046

Kemp R, Loorbach D (2005) Dutch policies to manage the transition to sustainable energy. In: Beckenbach F, Hampicke $U$, Leipert $C$, Meran G, Minsch J, Nutzinger HG, Pfriem R, Weimann J, Wirl F and Witt U (eds) Jahrbuch ökologische ökonomik: innovationen und transformation. Band 4, Metropolis, Marburg, pp 123-150

Lundvall BA (1992) National systems of innovation: towards a theory of innovation and interactive learning. Pinter Publishers, London

MacKenzie D (1992) Economic and sociological explanations of technological change. In: Coombs R, Saviotti P, Walsh V (eds) Technological change and company strategies: economic and sociological perspectives. Academic, London, pp $25-48$

Matsuoka Y (2005) A level of dangerous climate change and climate stabilization target for developing long-term policies (in Japanese). Environ Res Q 133:7-16

MA (Millennium Ecosystem Assessment) (2005) Ecosystems and human well-being: synthesis report. Island Press, Washington D.C.

McDowall W, Eames M (2004) Forecasts, scenarios, visions, backcasts and roadmaps to the hydrogen economy: a review of the hydrogen future literature for UK-SHEC. Policy Studies Institute (PSI), London

Nattrass B, Altomare M (1999) The natural step for business: wealth, ecology, and the evolutionary corporation. New Society Publ, Gabriola Island, B.C.

Newman L (2005) Uncertainty, innovation, and dynamic sustainable development. Sustainability: Science, Practice Policy $1: 25-31$

OECD (1993) OECD core set of indicators for environmental performance reviews. Environment Monographs No. 83, Organization for Economic-Cooperation and Development, Paris

Perrow C (1999) Normal accidents: living with high-risk technologies. Princeton University Press, Princeton

Pierson P (2000) Increasing returns, path dependence, and the study of politics. Am Polit Sci Rev 94:251-267
Rip A, Kemp R (1998) Technological change. In: Rayner S, Malone E (eds) Human choices and climate change. Battelle Press, Columbus, pp 327-399

Roco M, Bainbridge WS (2003) Overview: converging technologies for improving human performance. In: Roco $M$, Bainbridge WS (eds) Converging technologies for improving human performance: nanotechnology, biotechnology, information technology and cognitive science. Kluwer, Dordrecht, pp 1-27

Rosenberg N (1982) Inside the black box: technology and economics. Cambridge University Press, Cambridge

Rotmans J, Kemp R, van Asselt M (2000) Transitions \& transition management, the case of an emission-free energy supply. International Centre for Integrative Studies, Maastricht, The Netherlands

RS/RAE (Royal Society/Royal Academy of Engineering) (2004) Nanoscience and nanotechnologies: opportunities and uncertainties. Royal Society and Royal Academy of Engineering, London

Sartorius C (2005) Indicators for a sustainable technology development - a dynamic perspective. In Horbach $\mathbf{J}$ (ed) Indicator systems for sustainable innovation. Physica-Verlag, Heidelberg, pp 43-70

Sartorius C (2006) Second-order sustainability - conditions for the development of sustainable innovations in a dynamic environment. Ecol Econ 58:268-286

Science Council of Japan (2005) Japan vision 2050: principles of strategic science and technology policy toward 2020. Science Council of Japan, Tokyo

Sustainable Society Research Group (2005) Energy vision for a sustainable society (in Japanese). Institute of Industrial Science, University of Tokyo Press, Tokyo

UN (2002) Report of the world summit on sustainable development. A/CONF.199/20. United Nations, New York

UNEP/CBD (2000) The ecosystem approach: towards its application to agricultural biodiversity. Decision V/6. Nairobi

Unruh GC (2000) Understanding carbon lock-in. Energy Policy 28:817-830

Van Notten P, Rotmans J, van Asselt M, Rothman D (2003) An updated scenario typology. Futures 35:423-443 